\title{
Biological diversity of copepods and cladocerans in Mediterranean temporary ponds under periods of contrasting rainfall
}

\author{
Maria-José CARAMUJO ${ }^{1) *}$ and Maria-José BOAVIDA ${ }^{1,2)}$ \\ ${ }^{1)}$ University of Lisbon, Faculty of Sciences, Centre of Environmental Biology, Campo Grande, 1749-016 Lisbon, Portugal \\ ${ }^{2)}$ University of Lisbon, Faculty of Sciences, Department of Animal Biology, Campo Grande, 1749-016 Lisbon, Portugal \\ *e-mail corresponding author:mj.caramujo@fc.ul.pt
}

\begin{abstract}
The zooplankton communities of 5 temporary ponds in the Northern part of the Natural Park of the Southwest and Vicentina Coast (PNCSV), Southwestern Portugal, were studied during two consecutive years of contrasting rainfall. A total of ten cladoceran species and eleven copepod species (3 diaptomids, 5 cyclopoids and 3 harpacticoids) were recorded. The community structure varied along the hydrological period of the ponds. Some species were restricted to the early period of the pond (Diaptomus kenitraensis, Hemidiaptomus roubaui, Daphnia hispanica) while others started to build large populations in the middle of the hydroperiod and dominated the communities at the later stages of the hydroperiod: Dussartius baeticus and Ceriodaphnia reticulata dominated the larger ponds, while C. reticulata and Simocephalus exspinosus dominated the smaller ponds. Alpha and beta diversity of cladoceran and copepod species were calculated for the ponds of different hydroperiod length (i.e., water residence time) and area. Alpha diversity was defined as the total diversity of species associated with each pond throughout the annual hydrological period. Copepod and cladoceran communities associated with larger ponds were more diverse than the communities of smaller ponds. As several pond species occur in succession during the length of hydrological period, a longer hydroperiod (2006/2007) allowed for the establishment of a larger number of species than a shorter hydroperiod (2007/2008). Beta diversity was considered as the turnover of species in the gradient of pond area and was higher in the longer hydrological period than in the shorter hydrological period. The degree of diversity change between pairs of ponds was larger between any of the two smaller ponds and any of the larger ponds. This is the first study on the richness of planktonic micro-crustaceans in Portuguese temporary ponds. It is our purpose to increase the knowledge on these taxa to highlight the importance of including this little known, albeit unique, biological diversity when evaluating Mediterranean temporary ponds to conservation purposes.
\end{abstract}

Key words: Biodiversity, zooplankton succession, drought, Hemidiaptomus, Dussartius baeticus

\section{INTRODUCTION}

Traditional freshwater research has generally been waterbody-specific and focused on rivers, streams and lakes. Nevertheless, Mediterranean temporary ponds and their specialized taxa that resort to several life-history strategies to overcome the unpredictability of temporary environments have been receiving increasing attention (e.g., Wiggins et al. 1980; Miracle 1982; Wyngaard et al. 1991; Galindo et al. 1994; Serrano \& Toja 1998; Fahd et al. 2000; Boix et al. 2001; Bruno et al. 2001; Boix et al. 2004; Grillas et al. 2004a, b; Brucet et al. 2005; Serrano \& Fahd 2005; Frisch et al. 2006; Marrone et al. 2006; Fahd et al. 2007; EPCN 2008). In semi-arid regions, such as the Mediterranean region, temporary water bodies are important natural systems (Williams 2000) and have been included in the framework of the Ramsar Convention on Wetlands since 2002 (Anonymous 2002). In the Iberian Peninsula, temporary ponds are a conspicuous feature of the landscape although human pressure is responsible for the degradation of many ponds, especially of those outside nature reserves.

The most recent studies on the biodiversity of freshwater ponds in the Iberian Peninsula have stressed the need to assess their biodiversity value as a pre-requisite for many strategic conservation goals (see references above). In Portugal, the biodiversity of cladocerans and copepods of temporary ponds has not been surveyed although the studies on macro-crustaceans (Machado et al. 1999a, b; Korn et al. 2006), insects (Chaves 1999) and amphibians (Beja \& Alcazar 2003) all indicate the existence of large biological diversity in these habitats. Additionally, a large diversity has been recorded for micro-crustaceans inhabiting temporary ponds in Spain, including some endemic and rare species (Dussart 1967a; Miracle 1982; Alonso 1991, 1996; Fahd et al. 2000; Serrano \& Fahd 2005).

The communities of species in temporary ponds are structured by environmental variables among which the duration of the flood period (or hydroperiod) assumes paramount importance because of its ability to influence other environmental parameters (Rzóska 1961; Mahoney et al. 1990; Girdner \& Larson 1995; Fahd et al. 2000). These species that have adapted to the large environmental fluctuations of their habitat, interact with one another and compete for similar resources. As in other ecosystems, species will use different parts of the environmental gradient and profit from environmental heterogeneity to reduce competition (Whittaker 1972). 
Habitat heterogeneity in temporary ponds has been referred to be one of the forces enabling the existence of rich zooplankton communities (Green 1985; Galindo et al. 1994). This level of species diversity on a small scale has been defined as within-habitat or alpha diversity (Fisher et al. 1943; Whittaker 1960, 1967). The degree of change in species composition along different communities in the landscape, or along an environmental gradient, is defined as between habitat or beta diversity (Whittaker 1960). Here, we define beta diversity as the change in diversity between pairs of ponds of different flooding areas. Considering that seasonal patterns have been detected in the zooplankton composition of temporary ponds (Fahd et al. 2007), and that inter-annual variability of zooplankton communities reflects hydrometeorological fluctuations (Serrano \& Toja 1998) we have incorporated a temporal scale into our sampling. A cumulative survey of ponds is more suitable to assess biodiversity because it renders a higher number of taxa than extensive point surveys, and allows for the inspections of the mechanisms underlying taxon richness (see Fahd et al. 2007 and references therein). The periodical sampling of the ponds during two consecutive hydrological cycles enabled the determination of the effect of low rainfall on species richness.

With this study we intend to increase the knowledge on Cladocera and Copepoda diversity in temporary ponds assessing (i) the contribution of pond size, duration of flooding and water parameters to the observed changes in the abundance and distribution of species, and (ii) the influence of the length of the hydrological period on species diversity (alpha diversity) and on species turnover along the gradient of pond size (beta diversity).

\section{METHODS}

\subsection{Study area and sampling}

We have chosen a semi-natural area to study biodiversity in temporary ponds and the processes that drive it in the (near) absence of anthropogenic impacts. The survey was done by sampling five ponds fortnightly during the hydrological periods of 2006/2007 and 2007/2008, starting in the first and third weeks of December, respectively. Initially, seven ponds were included in the survey (Fig. 1), yet the ponds B15 and B44 did not fill in 2007/2008 and were removed from the quantitative analyses. The ponds are located within the Natural Park of the Southwest Alentejo and Vicentina Coast in Portugal (PNSACV), in sector B (Beja \& Alcazar 2003) on a coastal sandy plateau protected by consolidated dunes on the west, and by a curtain of pine and eucalyptus trees to the east. Human impacts on the region are restricted to sheep herding and physical trampling of pond margins during the dry periods. The climate is Mediterranean with oceanic influence. The soil is highly permeable and ponds fill mainly with rain water. During the sampling seasons rainfall varied from $487 \mathrm{~mm}$ in $2006 / 2007$ to $380 \mathrm{~mm}$ in 2007/2008 (Meteorological Institute Portugal, http://www.meteo.pt), and the flooded area and the hydroperiod of ponds differed sharply between the two seasons (Fig. 2). The nominal maximum surface area of the temporary ponds ranged from 0.4055 to 9.5938 ha yet, during the study period, the ponds never reached their maximum capacity and the flooded area was much reduced (maxima of 3 ha for ponds B20 and B27; see figure 2). Pond code follows Alcazar (1998). All ponds were temporary, drying in late spring, and both fish and crayfish were absent from the ponds. Either bordering or in the ponds, several plant species were present: Mentha pulegium and Mentha sp., Scirpus holoschoenus, Ranunculus peltatus Schrank, Ophioglossum sp., Potamogeton sp., Juncus sp. and one unidentified Characeae species.

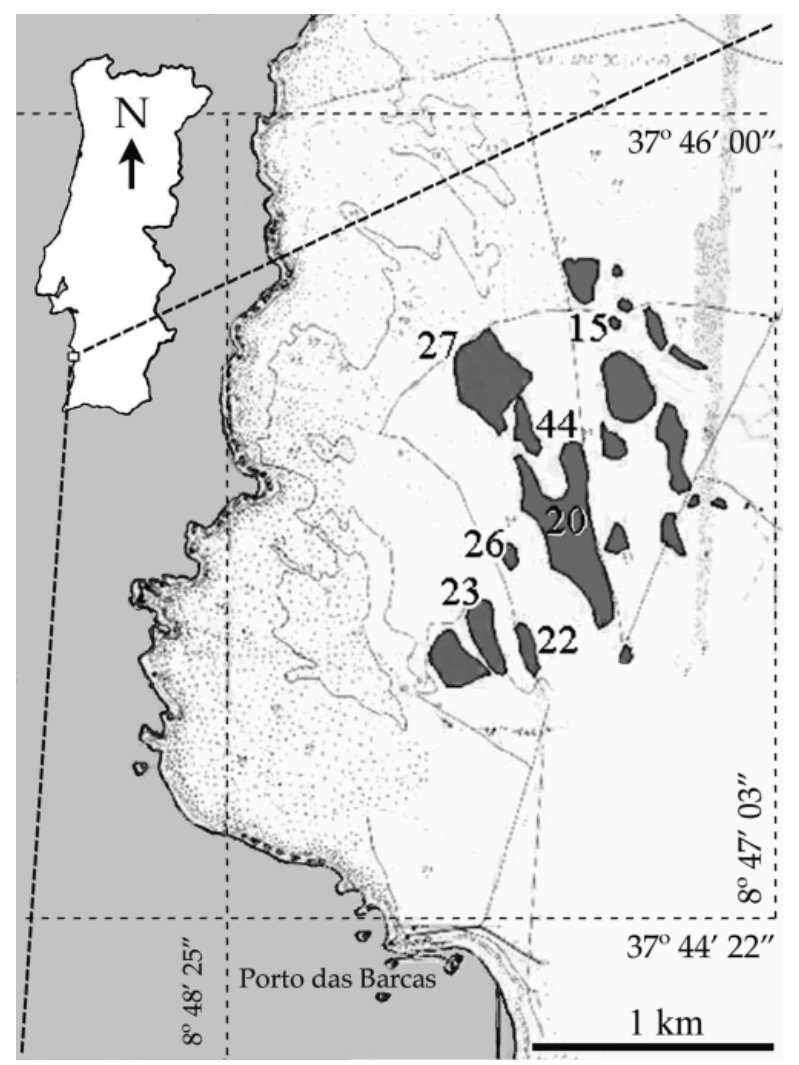

Fig. 1. Location of ponds (sector B) in the Natural Park of the Southwest and Vicentina Coast (PNCSV), southwestern Portugal. Pond code follows Alcazar (1998). Data from ponds B15 and B44 were removed from this study and the list of species there recorded is given in table 1 .

Water depth $(\mathrm{m})$, temperature $\left({ }^{\circ} \mathrm{C}\right)$, dissolved oxygen ( $\left.\mathrm{mg} \mathrm{O}_{2} \mathrm{~L}^{-1}\right)$, transparency (Secchi disc), conductivity $(\mu \mathrm{S}), \mathrm{pH}$, chlorophyll- $a$ (particle size fraction $<125$ $\mu \mathrm{m} ; \mu \mathrm{g}$ Chl $\left.-a \mathrm{~L}^{-1}\right)$, dissolved phosphorus content ( $\mu \mathrm{g} \mathrm{P}$ $\mathrm{L}^{-1}$ ) and flooded area (ha) were measured during the two hydroperiods. Water temperature in the ponds at $0.5 \mathrm{~m}$ depth varied between 13.3 and $25.2{ }^{\circ} \mathrm{C}$ and $\mathrm{pH}$ ranged 
2006/2007 $\quad \bigcirc_{2007 / 2008}$



Fig. 2. Area of the surveyed ponds in the hydrological periods of 2006/2007 and 2007/2008. Largest circles indicate a maximum area in 2006/2007 of 3 ha for ponds B20 and B27; maximum area in 2007/2008 of 1 ha for pond B27.

from 5.4 to 7.62 . Water physical and chemical parameters were measured in the field with hand-held probes (YSI, Texas, USA) and water samples were collected to measure Chl- $a$ and P. Chl- $a$ was determined using the fluorimetric method proposed by Yenstch and Menzel (1963) and adapted by Holm-Hansen \& Rieman (1978) for the extraction in methanol. Water filtered by 0.45 $\mu \mathrm{m}$ membranes was analysed for orthophosphate by the ascorbate-molybdate method (Murphy \& Riley 1962).

Triplicate zooplankton samples were collected using a plankton net ( $75 \mu \mathrm{m}$ mesh size) to make horizontal tows of 2-4 m length from the deep centre to the margin of the pond. Pilot sampling indicated that for these ponds with less than $1.5 \mathrm{~m}$ depth horizontal hauls at $\approx 0.5 \mathrm{~m}$ depth were ideal to sample all microcrustacea. The horizontal hauls were made from the centre of the pond to the vertices of an imaginary triangle fitting the pond. Ponds less than $8 \mathrm{~m}$ diameter were sampled in duplicate. All amphibians and macroinvertebrates retained by a $3 \mathrm{~mm}$ mesh sieve were excluded from the samples. Aquatic Crustacea living among macrophytes were collected using a 3-L van Dorn bottle and filtering the sample through a $75 \mu \mathrm{m}$ mesh sieve. The proportions of macrophyte area (sampled with Van Dorn bottle) and open area (horizontal hauls) of ponds were used to correct for the contribution of crustaceans living among macrophytes and of those living in the open water to the final abundance estimates. Samples were anaesthetised in carbonated water, fixed in sugar saturated formaldehyde and stored in glycerinated 70\% ethanol. Macroinvertebrate taxa in the samples were identified at family level (Tachet 2000; Thorp \& Covich 2001) to inspect the presence of zooplankton predators and were not included in the analyses of species richness. The potential zooplankton predators included Tricladida (flatworms), Odonata larvae (dragonflies and damselflies), Coleoptera (water beetles), Diptera larvae and Acari (mites). We disregarded Araneae (spiders) as possible predators because while the predaceous deuto- nymphs and adults of water mites can be considered potential predators of freshwater zooplankton, spiders maintain a conservative way of life as essentially terrestrial predators (Proctor \& Pritchard 1989).

The identification of copepods followed Dussart (1967b, 1969) and Kiefer (1978), and the identification of cladocerans followed Scourfield \& Harding (1966) and Alonso (1996). The absence of any checklist of cladocerans and copepods from temporary ponds prompt us to incorporate the species present in ponds B25 and B44 in our list of species for the area (Tab. 1).

\subsection{Numerical and statistical analyses}

The existence of structural factors responsible for the variation of the abundance of cladoceran and copepod species in the sampled ponds was explored by multivariate redundancy analysis (RDA, ter Braak 1995) using the program CANOCO 4.5 (Legendre \& Legendre 1998). A linear model of ordination was chosen because preliminary detrended correspondence analysis (not presented here) have shown that "species turnover" along the first axes was close to two standard deviation units. Thus, the application of an uni-modal ordination model to the data set was not recommended (ter Braak 1995). The response variables were the abundance of copepod and cladoceran species. The explaining variable set included average Chl- $a$ biomass, dissolved phosphorus concentration $\left(\mu \mathrm{g} \mathrm{P} \mathrm{L}^{-1}\right)$, dissolved oxygen $\left(\mathrm{mg} \mathrm{O}_{2} \mathrm{~L}^{-1}\right)$, conductivity $(\mu \mathrm{S})$, water temperature $\left({ }^{\circ} \mathrm{C}\right)$, pond area (ha), $\mathrm{pH}$, pond age from filling, and total abundance of potential predators (PDT). The variable pond depth was excluded because it was highly correlated with pond area. RDA was applied on a covariance matrix to avoid the attribution of large weight to rare categories (ter Braak 1995), and variables were $\log (n+1)$ transformed to reduce the influence of very large numbers. The zooplankton abundance variation was further related to each of the three variable sets (i.e., water parameters, pond parameters and biological parameters) of predictor variables separately through the application of partial 
Tab. 1. List of species sampled in temporary ponds at the northern region of PNSCV during two hydrological periods $(2006 / 2007$ and $2007 / 2008)$. * filled only in 2006/2007, data were not considered for the present study.

\begin{tabular}{|c|c|c|c|c|c|c|c|}
\hline Species & $\mathrm{B} 23$ & $\mathrm{~B} 22$ & B26 & $\mathrm{B} 20$ & $\mathrm{~B} 27$ & $\mathrm{~B} 15^{*}$ & $\mathrm{~B} 44 *$ \\
\hline Area (ha, maximum nominal) & 2.075 & 0.854 & 0.406 & 9.594 & 6.188 & 0.125 & 1.047 \\
\hline Area (ha, maximum in $2006 / 2007$ ) & 0.2 & 0.6 & 0.35 & 3.00 & 3.00 & 0.01 & 0.30 \\
\hline Area (ha, maximum in $2007 / 2008$ ) & 0.1 & 0.3 & 0.2 & 0.8 & 1.0 & - & - \\
\hline \multicolumn{8}{|l|}{ CLADOCERA } \\
\hline Alona guttata (G.O. Sars, 1862) & & + & & & + & + & \\
\hline Alona quadrangularis (O. F. Müller, 1776) & & & & + & + & + & \\
\hline Alona rectangula (G.O. Sars, 1862) & & + & + & & & + & + \\
\hline Bosmina longirostris (O. F. Müller, 1776) & + & & & & & & \\
\hline Ceriodaphnia reticulata (Jurine, 1820) & + & + & + & + & + & + & + \\
\hline Chydorus sphaericus (O. F. Müller, 1776) & + & + & + & + & + & + & + \\
\hline Daphnia (Ctenodaphnia) hispanica (Glagolev and Alonso, 1990) & & & + & & + & & \\
\hline Daphnia obtusa (Kurz, 1875) & & & & + & + & & \\
\hline Oxyurella tenuicaudis G.O. Sars, 1862 & & & & & & + & \\
\hline Pleuroxus laevis (G.O. Sars 1862) & & & & & & + & + \\
\hline Scapholebris rammneri (Dumont and Pensaert, 1983) & & & + & & + & & \\
\hline Simocephalus exspinosus (DeGeer, 1776) & + & + & + & + & + & + & + \\
\hline \multicolumn{8}{|l|}{ COPEPODA } \\
\hline Dussartius baeticus (Dussart, 1967) & & & + & + & + & + & + \\
\hline Diaptomus kenitraensis (Kiefer, 1926) & + & & + & + & + & & + \\
\hline Hemidiaptomus roubaui (Richard, 1988) & & & + & + & + & & \\
\hline Megacyclops viridis (Jurine, 1820) & + & + & + & + & + & + & + \\
\hline Thermocyclops dybowskii (Lande, 1890) & + & + & & + & + & + & + \\
\hline Eucyclops serrulatus (Fischer, 1851) & + & & & & + & & \\
\hline Eucyclops speratus (Liijeborg, 1901) & + & & & & & & \\
\hline Diacyclops bicuspidatus odessanus (Schmankevitch 1875) & + & + & + & + & + & + & + \\
\hline Attheyella (Neomrazekiella) trispinosa (Brady, 1880) & & & + & + & + & + & + \\
\hline Bryocamptus (Bryocamptus) minutus (Claus, 1863) & & & & + & + & & \\
\hline Canthocamptus microstaphilinus var. monardi (Roy 1927) & & & & + & & & \\
\hline
\end{tabular}

RDA. Each of these variable sets was individually tested as explanatory variable while holding the other two sets as covariates (ter Braak \& Smilauer 1998)

The diversity indices of Hill (1973) were applied to calculate alpha diversity.

$N_{0}$ is the total number of species present at each sampling date, regardless of their proportional abundance. In order to incorporate the temporal scale into alpha diversity, the cumulative $N_{0}$ was also calculated for the whole hydroperiod. The variability of the cumulative $N_{0}$ between 2006/2007 and 2007/2008 was tested using the individual pond hydrological period (in weeks) as covariate (ANOVA, SPSS Statistical Package, SPSS Inc., USA). $N_{0}$ was related to the abundance of potential predators through the application of the non-parametric Spearman correlation coefficient (SPSS Statistical Package, SPSS Inc., USA).

$N_{l}$ was calculated as the exponential of the entropy index of Shannon-Wiener (Hill 1973):

$$
N_{l}=\exp \left(H^{\prime}\right)
$$

with $H^{\prime}=-{ }^{\mathrm{n}} \sum_{\mathrm{i}=1} p_{i} \ln p_{i}$ and $p_{i}=N i / N t$ or the relative importance of the $i^{\text {th }}$ species.

Beta diversity measures the degree of species turnover in species composition along the gradient of pond area in both hydrological periods, and was calculated as Cody's $\beta_{\mathrm{c}}$ (Wilson \& Schmida 1984):

$$
\beta_{\mathrm{c}}=(g H+l H) / 2
$$

where $g(H)$ is the number of species gained and $l(H)$ the number of species lost in the cumulative survey for each year, when moving along the area gradient from smaller to larger ponds.

\section{RESULTS}

\subsection{The communities of copepods and cladocerans}

Ten cladoceran species, plus three calanoid, five cyclopoid and three harpacticoid copepod species were present in the five ponds surveyed during two consecutive hydrological periods (2006/2007 and 2007/2008) (Tab. 1). During both sampling periods, water residence time in ponds $\mathrm{B} 22$ and $\mathrm{B} 23$ was shorter than in other ponds (B20, B26, B27; Fig. 2). In ponds B22 and B23, despite having flooding areas similar to pond B26, water depth was always below $0.6 \mathrm{~m}$ at the deepest spots in 2006/2007 and below $0.3 \mathrm{~m}$ in 2007/2008. The flooded area of ponds B22 and B23 was unstable because of their small depth, and were often equal or smaller than that of B26. Pond B26 is a circular pond in a steep depression of the terrain which ensured that water depth was only reduced below $0.4 \mathrm{~m}$ when the pond started to dry. Ponds B20 and B27 were the largest ponds. Higher rainfall occurred earlier in the autumn of 2006 than in 2007 and the ponds filled two weeks sooner in 2006 (late November) than in 2007 (mid December). In the season 2006/2007 the ponds remained filled during a longer period and covered a larger area than in 2007/2008 (Fig. 2). 
Pond B20

$\square$ Dussartius baeticus $\square$ D. baeticus - adults $\square$ Diaptomus kenitraensis

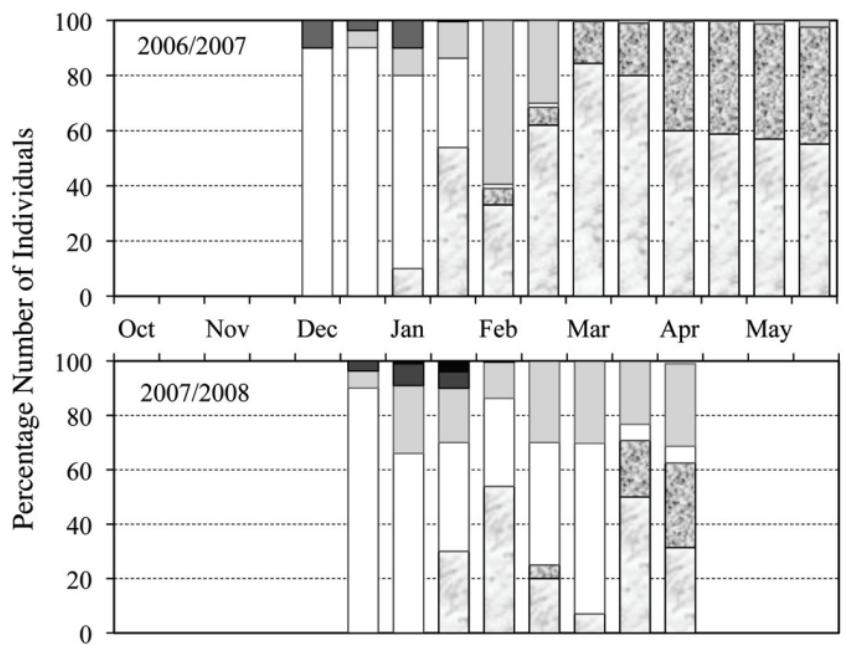

Pond B27

$\square$ D. kenitraensis - adults $\square$ Hemidiaptomus roubaui $\boldsymbol{\square}$. roubaui - adults

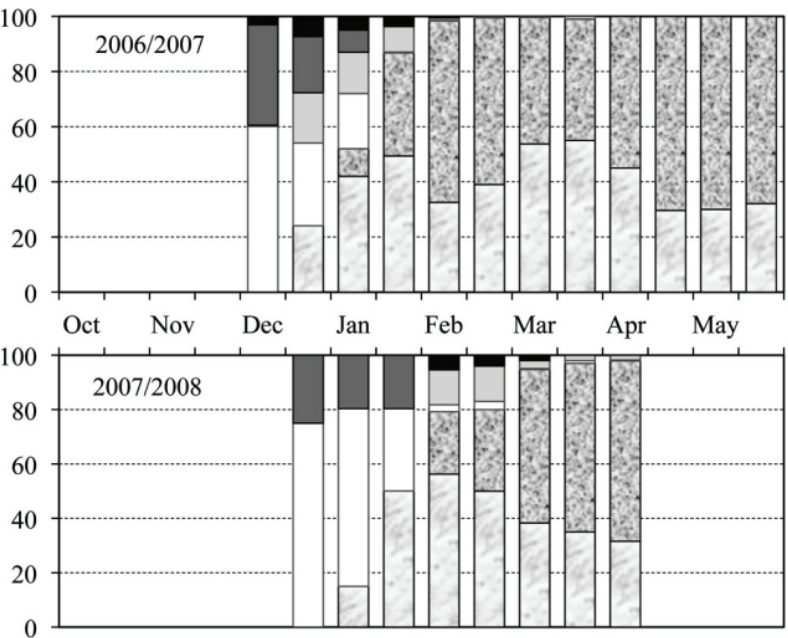

Fig. 3. Temporal succession of calanoid populations in the largest ponds (B20 and B27). The relative percentage of each calanoid population is given separately for copepodites and adults.

During the first week of January, when the effects of pond dryness were not expected to occur in either hydroperiod, the total abundance of cladocerans plus copepods was significantly highest in the intermediate area pond $(\mathrm{B} 26 ; \mathrm{F} 4,30=512.41, p<0.001)$ and was not influenced by the amount of rainfall (year effect F1,30 = $0.01, p>0.05$; data not shown). During both hydrological periods, in the larger ponds (B26, B20 and B27) the initial zooplankton community was dominated by the calanoids Hemidiaptomus roubaui (Richard 1988) and Diaptomus kenitraensis (Kiefer 1926), accompanied by the large cladoceran Daphnia (Ctenodaphnia) hispanica (Glagolev \& Alonso 1990) (see Fig. 3 for calanoid succession). The populations of both $H$. roubaui and $D$. kenitraensis were univoltine and produced several clutches of resistant eggs at the intermediate phase of the hydrological period. When the populations of the large calanoids were mainly constituted of late copepodite stages and adults (intermediate hydrological phase) the small calanoid Dussartius baeticus (Dussart 1967) started to build large populations accompanied by Daphnia obtusa (Kurz 1875) and the cyclopoid Diacyclops bicuspidatus odessanus (Claus 1857). At a later stage, D. baeticus dominated the zooplankton community accompanied by Ceriodaphnia reticulata (Jurine 1820) and the cyclopoid Thermocyclops dybowskii (Lande 1890). The smaller ponds (B22 and B23) were always dominated by populations of cyclopoids in the earlier phase of the ponds, and in the later phase by large populations of Cerioadaphnia reticulata (Jurine 1820), Simocephalus exspinosus (DeGeer 1776) and ostracods.

When RDA was applied to zooplankton abundance data, $38.8 \%$ of copepod and cladoceran abundance variability could be explained by the variation in environmental variables (pond area increments, pond age, $\mathrm{pH}$,
$\mathrm{dP}$, conductivity, temperature, $\mathrm{O}_{2}$, Chl- $a$ and potential predator abundance; Fig. 4A). The first two axes of the model explained $32.2 \%$ of zooplankton variability. The first axis is significantly correlated with pond age $(r=$ $0.886)$ and inversely related to pond area increment $(r=$ $-0.611)$ while the second axis was directly related to water conductivity $(r=0.703)$ and inversely related to the age of the pond $(r=0.738)$. The abundance of potential predators contributed little to explain the variation in zooplankton abundance $(r=0.113$ and $r=$ 0.125 with first and second axis, respectively). Sites occurring at the left side of the plot represent the earlier communities i.e. dominated by $H$. roubaui, D. kenitraensis and $D$. (C.) hispanica in larger ponds, and $D$. bicuspidatus odessanus and Eucyclops serrulatus (Fischer 1851) in smaller ponds. Sites occurring at the upper right quadrant represent the latter communities of the smaller ponds (B23 and B22) while the sites occurring at the lower right quadrant represent the latter communities of larger ponds (B26, B20, B27; Fig. 4B). In the period 2007/2008 all ponds sampled in the latter dates shifted towards the upper right quadrant, as the area of the larger ponds rapidly decreased and these became more similar to the smaller ponds in the period 2006/2007 (Fig. 4C). During 2007/2008 there were large populations of small cladocerans in all ponds, including the ponds B20 and B27 that in 2006/2007 exhibited large populations of the calanoid D. baeticus.

Variation partitioning by redundancy analyses showed that only $27.5 \%$ of copepod and cladoceran variation out of $38.8 \%$ could be explained by the individual sets of variables (Fig. 5). The remaining 11.3\% of copepod and cladoceran assemblage variability could not be significantly ascribed to any set of environmental variables and was shared by the three sets. 

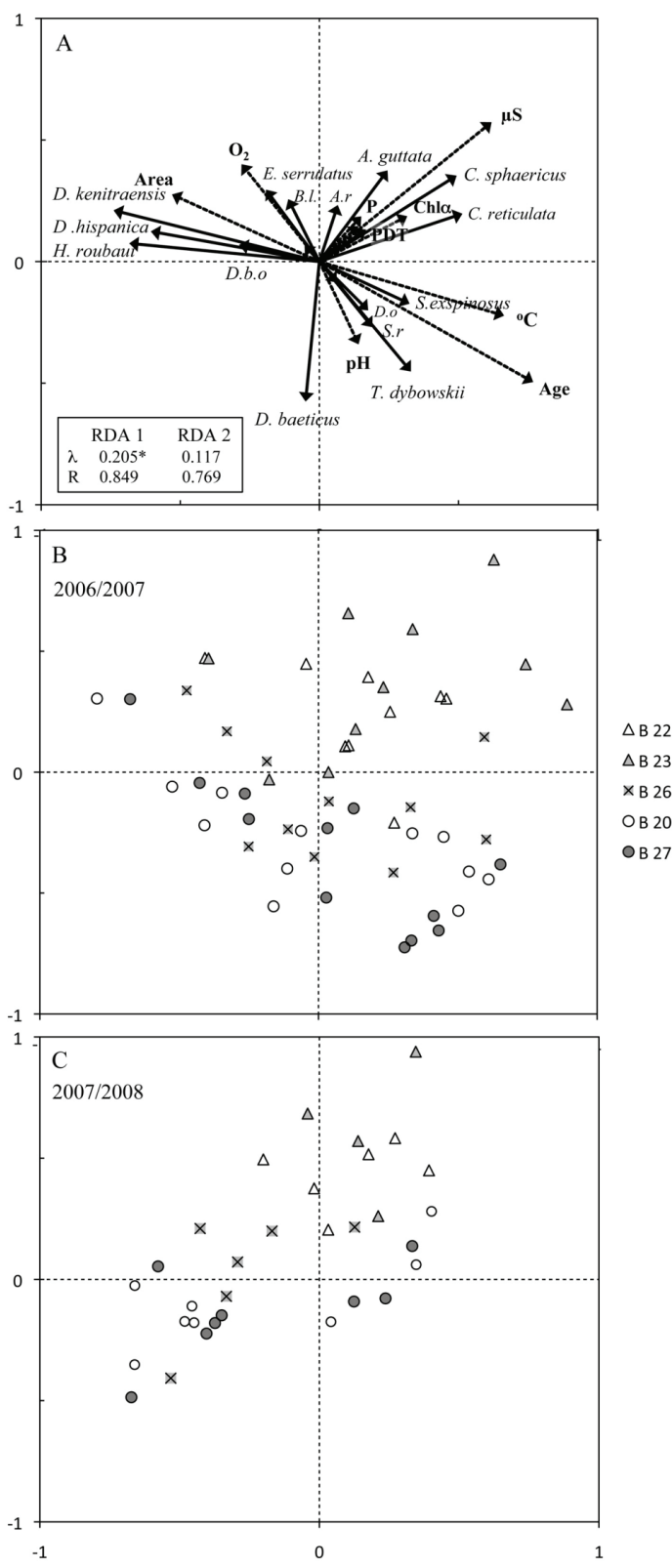

Fig. 4. Biplots from redundancy analysis for cladoceran and copepod species (black solid arrows). Species names as in table 1 plus D.b.o. = Diacyclops bicuspidatus odessanus, B.1. = Bosmina longirostris, A.r. = Alona rectangula, D.o. $=$ Daphnia obtusa, S.r. = Scapholebris rammneri. Diagrams depict the effect of environmental variables (dotted arrows): Algal biomass (Chl- $a)$, orthophosphate concentration (P), dissolved oxygen $\left(\mathrm{O}_{2}\right)$, conductivity $(\mu \mathrm{S})$, water temperature (Temp), pond area (Area), $\mathrm{pH}$, pond age from filling (Age) and total abundance of potential predators (PDT). Ordination axes were rescaled to range from -1.0 to 1.0. Lines representing variables depart from the origin in the direction of maximum value and their length is proportional to the maximum rate of change (Panel A). The Eigenvalues $(\lambda)$ and the species-environment correlations $(\mathrm{R})$ are indicated for each canonical axis. * indicate statistical significance of the axis. Large ponds in 2007/2008 (panel C) score mainly to the upper side of the plane while large ponds in 2006/2007 (panel B) score mainly to the lower side of the plane.

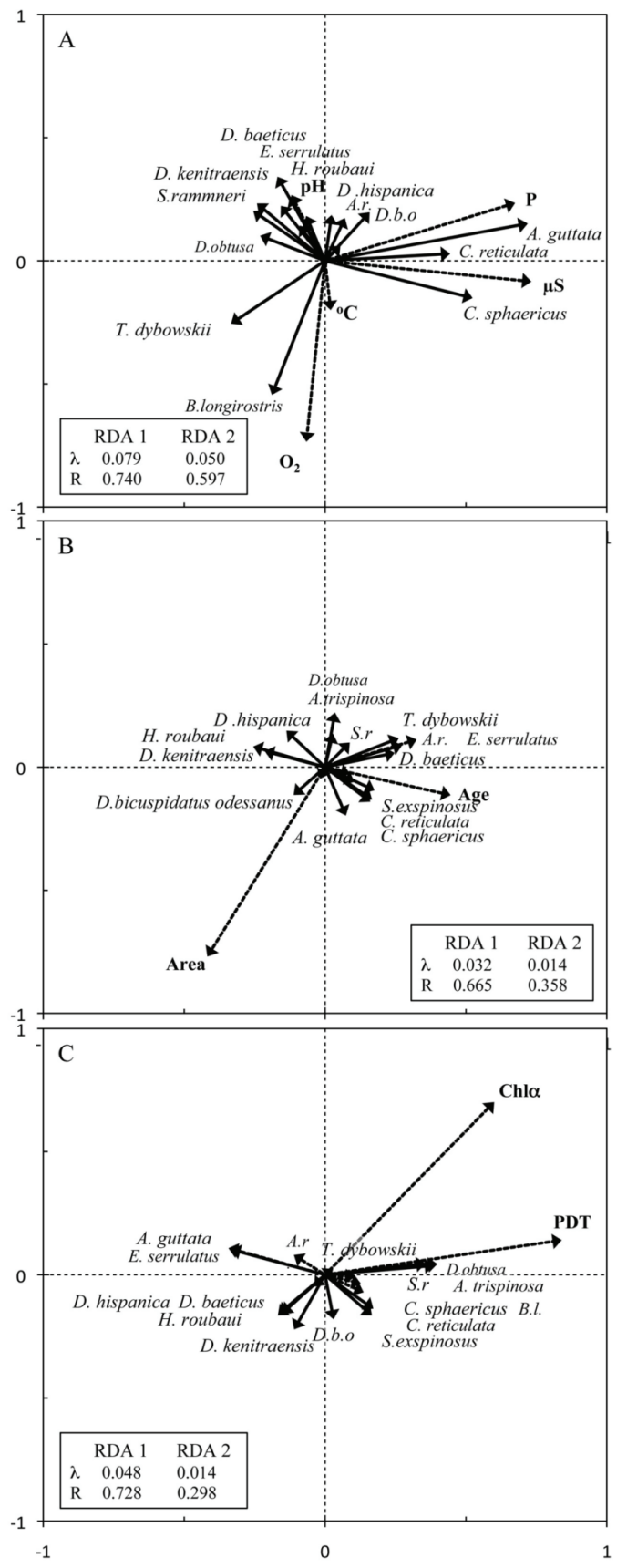

Fig. 5. Biplots from partial redundancy analyses for copepod and cladoceran assemblages. Diagrams depict the effects of each set of variables after partialling out the other environmental variables. Dotted lines indicate the environmental and solid-line arrows are the species variables. Ordination scales were rescaled to range from -1.0 to 1.0 . See legend of figure 4 and table 1 for abbreviations.

The content of orthophosphate and water conductivity explained $10 \%$ of the small proportion of assemblage variance ascribed to strictly environmental variables (total $=16.7 \%$, Fig. $5 \mathrm{~A}$ ) while pond age and flooding area variation explained only $4.6 \%$ of assemblage variation. The variation in algal biomass 
B 22



B 23

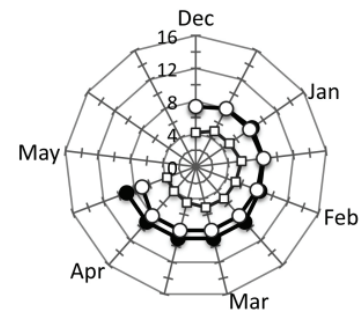

B 26

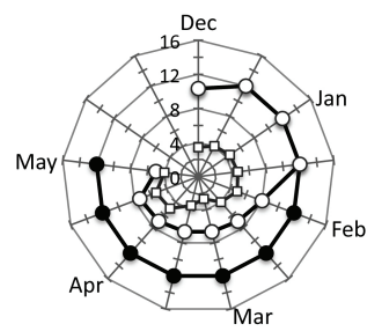

B 20

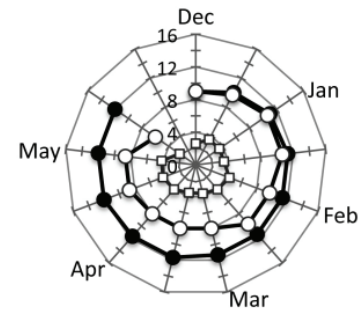

B 27

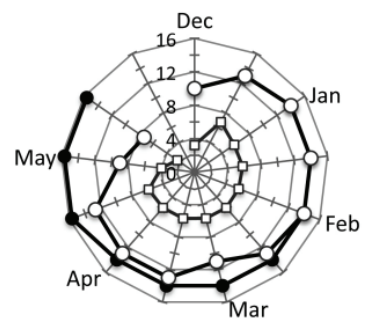

$2007 / 2008$
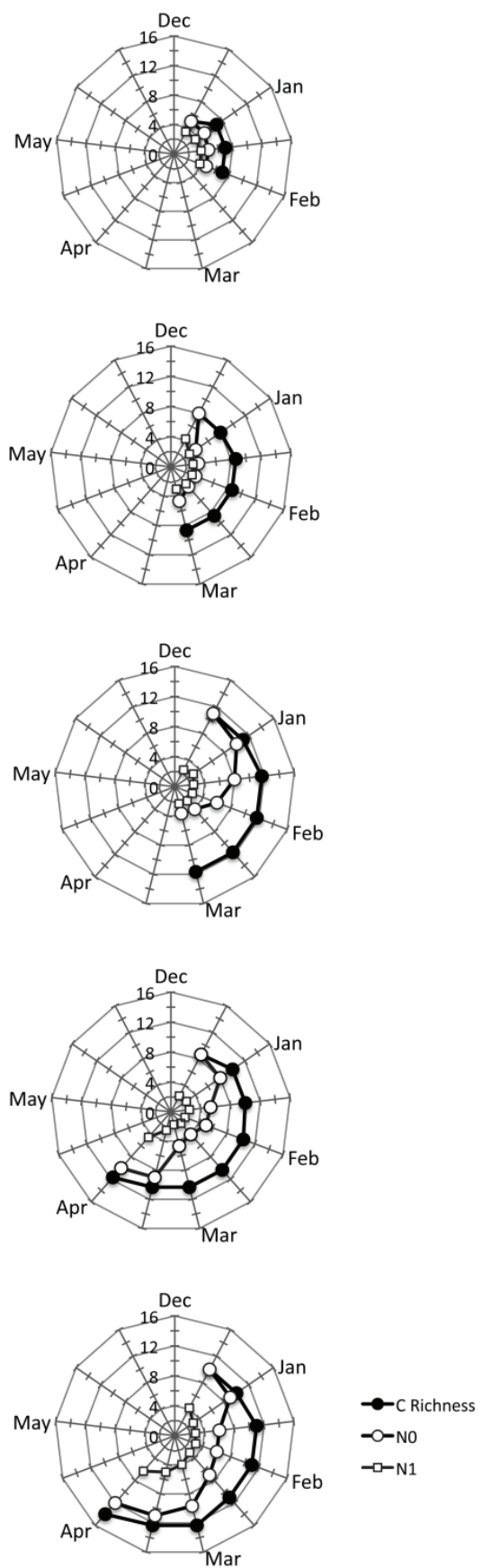

Fig. 6. Radial graphs depicting the cumulative species richness (C Richness), and Hill's indices $N_{0}$ and $N_{l}$ at each sampling date. The age of the pond follows a clock-wise direction of the axes in the graphs.

and predator abundance had little influence in favouring the abundance of small crustacean species relative to large species, explaining $6.2 \%$ of assemblage variation.

\subsection{Alpha diversity}

Species richness per pond $\left(N_{0}\right)$ varied with the age of the pond and maximum pond area during the hydrological periods (Fig. 6). Alpha diversity indices $\left(N_{0}\right.$ and $\left.N_{l}\right)$ were higher for larger ponds than for smaller ponds, and higher in 2006/2007 relative to 2007/2008 (see Fig. 6). The cumulative species richness of the ponds was significantly lower in the period of less rainfall, indicating that some species were not present in $2007 / 2008\left(\mathrm{~F}_{(1,9)}=\right.$ $10.38, p<0.05$; Fig. 7). $N_{0}$ was not significantly correlated with the abundance of potential predators in either hydroperiod, although there was a sharp increase 
in the abundance of water mites after mid April 2007 ( $>3.5$ individuals $\mathrm{L}^{-1}$, data not shown), when $N_{0}$ decreased in the larger ponds (maximum Spearman's $r=$ -0.553 for pond $\mathrm{B} 27, p>0.05$ ).

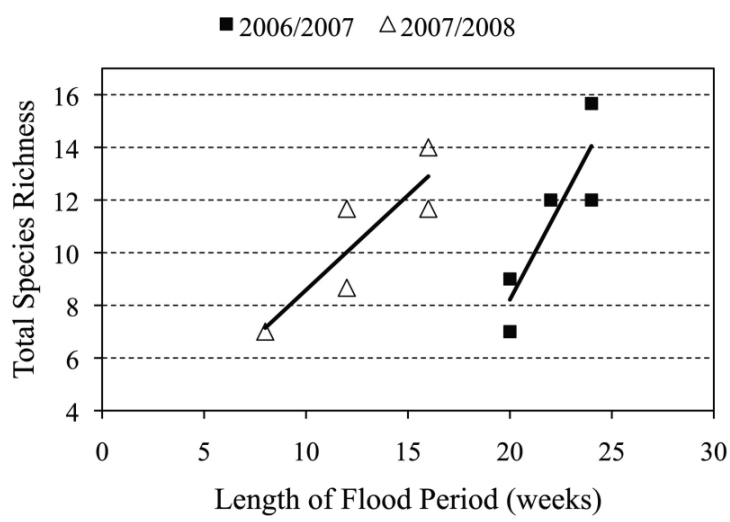

Fig. 7. Relationship between the length of the flood period in each pond and total species richness during two annual hydroperiods. Adjusted $r^{2}(2006 / 2007)=0.705 ; \mathrm{t}$ _slope $=$ $3.257, p=0.047$; adjusted $r^{2}(2007 / 2008)=0.682 ;$ t_slope $=$ $3.092, p=0.054$. The curves are significantly different, $\mathrm{F}(1,9)$ $=10.38, p<0.05$.

\subsection{Beta diversity among ponds}

To compare the degree of species turnover in species composition along the gradient of pond area we have calculated the values of Cody's beta diversity indices between each pond and the other 4 ponds in the area, and along the gradient of pond size in both sampling periods (Fig. 8). To compare Cody's $\beta_{\mathrm{c}}$ between pairs of ponds we have plotted the values in circular graphs to enable the rapid visualization of the change in terms of absolute number of species along the pond size gradient (Fig. 8A, B). Beta diversity was lower between ponds B22 and B23 ( $\beta_{\mathrm{c}}=2$, smaller ponds) and between ponds B20 and B27 ( $\beta_{\mathrm{c}}=2$, larger ponds) regardless of the duration of the yearly flooding. The diversity change was largest between the largest pond (B27) and the smaller ponds (B22 and B23) in the year of higher rainfall $(2006 / 2007)$. The diversity change $\left(\beta_{c}\right)$ between any pairs of small and intermediate, small and large, and intermediate and large ponds was smaller in the flooding period of 2007/2008 relative to the period of 2006/2007 (Fig. 8A, B).

When comparing pairs of ponds along the gradient of pond area, beta diversity was lower in 2007/2008 relative to 2006/2007 (Fig. 8C, D). The largest turnover of species was observed between pond B26 (intermediate area) and both the smaller and larger ponds in $2006 / 2007$, while in $2007 / 2008$ species turnover was more similar between pairs of ponds in the gradient. A smaller depth and the early dry of pond B26 in $2007 / 2008$ relative to $2006 / 2007$ may have prevented the appearance of some species which were present in the previous hydroperiod (e.g., Daphnia obtusa and Dussartius baeticus).
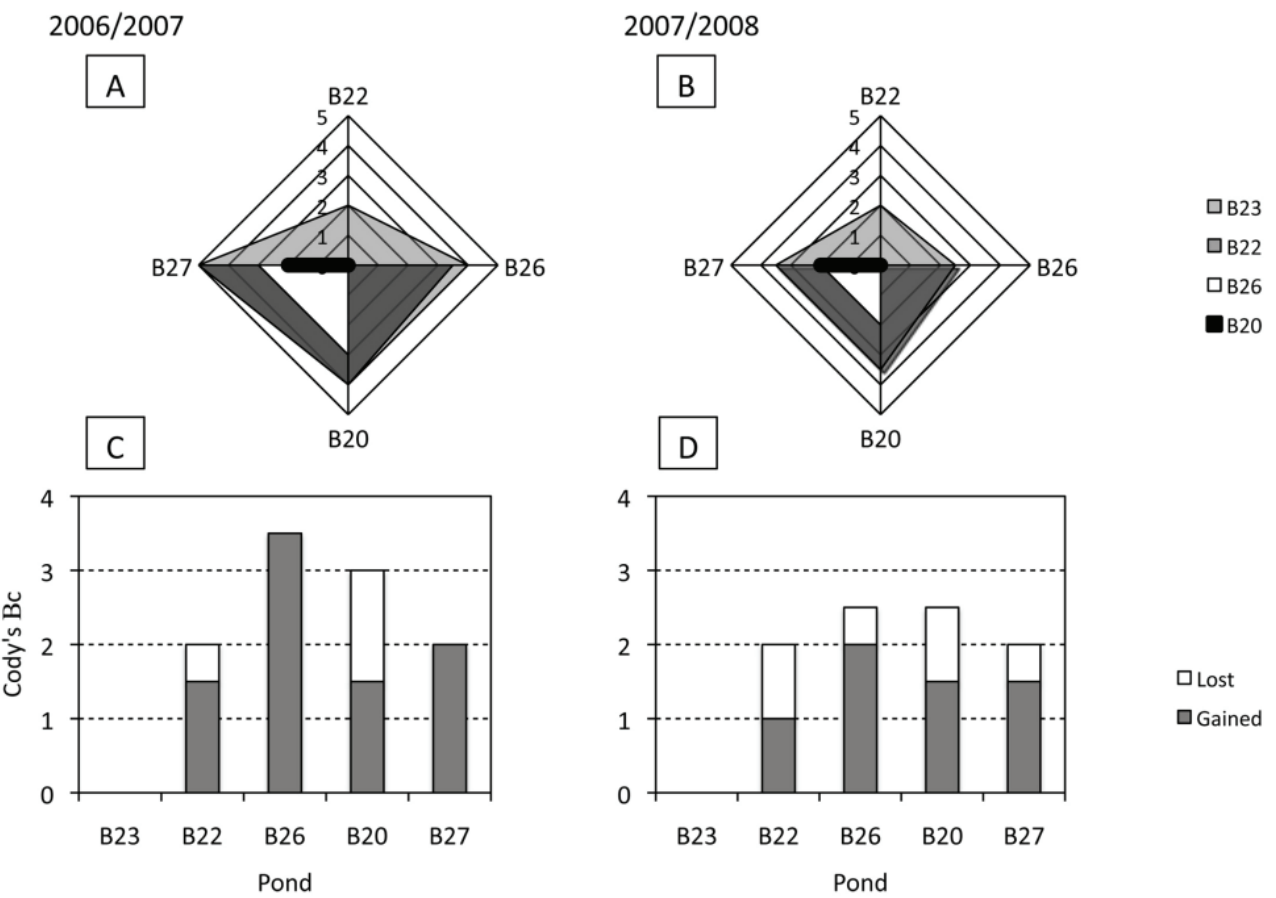

Fig. 8. Radial graphs depicting Cody's $\beta_{c}$ indices of beta diversity calculated between each pair of ponds (panels $\mathbf{A}$ and $\mathbf{B}$ ). The direction of area size increase of the ponds follows a clock-wise direction of the axes in the graphs. Panels $\mathbf{C}$ and $\mathbf{D}$ depict Cody's $\beta_{\mathrm{c}}$ indices between pairs of ponds in the area gradient. 


\section{DISCUSSION}

\subsection{Communities of copepods and cladocerans}

The surveyed ponds contain rich communities of copepods and cladocerans with a specific composition and population abundance similar to those in other locations of the Iberian Peninsula (e.g., Doñana National Park in SW Spain, Fahd et al. 2000 \& references therein). Divergence in the abundance of copepods and cladocerans in the winter was low between the two sampled hydrological periods, indicating that hydroperiod length was of small relevance for species abundance before the pond started to dry. However, the community composition was less diverse during the period of lower rainfall, since a longer hydroperiod favours a larger cumulative community richness as it has been recorded in ponds in Doñana National Park, Spain (Serrano \& Fahd 2005; Frisch et al. 2006). Such lower diversity during the shorter hydroperiod indicates the failure of some species to either colonize or hatch in the ponds.

The age of the pond and water conductivity were the most important variables creating environmental gradients that explain the observed variability of the copepod and cladoceran assemblages during both hydroperiods. However, the measured environmental factors only explained $\approx 40 \%$ of the variation in copepod and cladoceran assemblages, suggesting the existence of other important factors such as the quality of available food, not assessed during this study. In the larger ponds, the seasonal succession of species seemed to be mostly dependent on the time since the onset of flooding (age) on the submersion period and temperature, and to a lesser extent, on $\mathrm{pH}$. The conductivity gradient (thus associated with time duration of the submersion period and increase in algal biomass measured as Chl- $a$ ) explained mainly the variance in the communities of the smaller ponds where greater changes in conductivity along the age of the pond were recorded. Minimum conductivity values were always recorded at the beginning of the hydroperiods as previously noted by Fahd et al. (2000). Serrano \& Toja (1995) also observed that after very wet winters seasonal ponds become similar among themselves while, when moderate rainfall follows, the ionic and nutrient contents of each pond evolve differently. It is likely that the variation in conductivity is more acute in smaller ponds than in larger ponds because smaller ponds dry faster than larger ponds. The importance of conductivity as a structuring factor of crustacean community becomes apparent when the effect of strictly hydrological variables (pond submersion time and submerged area variation) and biological variables (Chl- $a$ biomass and potential predator abundance) are held constant. When all variables are considered together to create environmental gradients, the time since the onset of flooding (age of the pond) is the main regulator of crustacean communities. However, when the environmental variables are considered as separate sets it is revealed that other factors explain a larger variation of the communites than age alone. This suggests that age of the pond (as time since first flooding) possibly regulates communities by regulating the variation of other environmental variables (e.g., conductivity).

\subsection{Diversity of species}

The species richness at discrete times $\left(N_{0}\right)$ was similar to the values recorded by other authors in ponds with a 3-5 month hydroperiod (Galindo et al. 1994; Fahd et al. 2000; Frisch et al. 2006). The authors point out that a decrease in richness in ponds with longer hydroperiods may be related to the presence of predators. In this study, fish and crayfish were absent, and the potential predators were mainly insects and water mites (Acari) that seemed to have exerted a small predatory pressure on the zooplankton communities. All ponds contained abundant vegetation and that may have contributed to the high richness of cladocerans and cyclopoid copepods in the smaller ponds during the shorter hydroperiod (Alonso 1996; Frisch et al. 2006). The presence of aquatic vegetation increases the complexities of habitats (Van den Brink et al. 1994) and creates natural refuges (Shapiro 1990) that in turn favour zooplankton species richness.

The turnover of species along the gradient of pond size was generally higher during the longer hydroperiod. In this small region where the small extent of the physical barriers among the ponds would favour species exchange among these aquatic systems, it seems likely that the environmental differences in pond characteristics prevented species from colonizing or hatching in the smaller ponds, probably as a consequence of unfulfilled ecological requirements (e.g., minimum volume of water was insufficient to support the species). Certain species may have a threshold of flooding time length or water depth required for the establishment of populations. It is likely that the relationship between hydroperiod length and species turnover in the region changes beyond that threshold, and species richness (alpha diversity) becomes similar among ponds in periods of high rainfall. It would be interesting to verify, during a period of high rainfall, if all species could be found in all ponds in the region, regardless of their ability to later establish themselves in the individual pond communities. During unpredictable climatic periods, it would be reasonable to identify and protect the ponds in a region that most often would offer a suitable habitat for the richest crustacean communities.

\subsection{Relevance of micro-crustaceans for conservation}

As previously observed for Spain, some of the species recorded in this study are of North African or of Ethiopic origin (Miracle 1982). The typical calanoid assemblage in the area contains the species Dussartius baeticus, Diaptomus kenitraensis and Hemidiaptomus 
roubaui. Copepod assemblages in temporary steppe ponds in Spain characteristically contain the calanoids Mixodiaptomus incrassatus and Hemidiaptomus roubaui (Miracle 1982; Alonso 1987). However, in the ponds of Doñana, calanoid assemblages with $D$. kenitraensis and H. roubaui may occur (Fahd et al. 2000; Serrano \& Fahd 2005; Fahd et al. 2007). Miracle (1982) and Alonso (1978) noted that D. kenitraensis is a species of flat lands and low altitude and typically Lusitanean i.e., occurring in the western region of the Iberian Peninsula (Portugal and western Spain). The presence of the Atlantic Ocean results in a mild climate in this region, by contrast with the inner Peninsula where the climate is harsher (Alonso 1978).

This is, to our knowledge, the first report on the occurrence of Dussartius baeticus in temporary ponds in the south of Portugal (see Fidalgo \& Monteiro 2004 for its distribution in reservoirs north of River Tagus). Dussartius baeticus has been considered endemic of temporary ponds in SE Spain although its presence in the study area indicates that its distribution range may be wider than acknowledged (Dussart 1967a; Alonso 1978). Dussartius baeticus is considered a vulnerable (D2) taxon since 1996 (IUCN Red List of 2008; Reid 1996) and its presence in the surveyed ponds asserts the urgency of effectively protecting it. Low rainfall in consecutive years creates an additional stress to the maintenance of certain pond species, especially those hatching later in the seasonal succession such as $D$. baeticus. Considering that the species hatches from a propagule, the recurrent premature dryness of a pond may prevent the populations from producing resistant stages and replenishing the propagule stock necessary to ensure the existence of the species in the following years.

\section{CONCLUSIONS}

In general, environmental parameters seem to interact with one another to structure the crustacean communities in the region. The existence of environmental gradients in temporary ponds explains less than $40 \%$ of species variability in a small region where stochastic perturbation (e.g. unpredictable dryness of ponds) may be of paramount importance in periods of low rainfall. A longer hydroperiod in ponds and large pond area seems to favour the establishment of a larger number of species although ponds of intermediate size that stay flooded for 4 months may ensure the succession of species, and effectively support a large number of species.

The identification of ponds inhabited by rare species such as D. baeticus and D. kenitraensis contributes with valuable information for the protection efforts developed throughout the European Union to halt the loss of biodiversity by 2010 (see Countdown 2010: http:// countdown2010.net/about/partners.html). As noted by the Commission of the European Communities (2006) the risks faced by many invertebrates are unknown, largely because this assessment has not been done because of the lack of data. As Collinson et al. (1995) stated, the conservation of temporary ponds should seek to protect all taxa, and micro-crustaceans should be included in future conservative legislation.

\section{ACKNOWLEDGMENTS}

We wish to thank C.C.C.R. de Carvalho for assistance in the collection of samples, and the reviewers whose suggestions contributed to the improvement of an earlier version of this manuscript. This study was made possible by grant SFRH/BPD/25259/2005 awarded to MJC by Fundação para a Ciência e a Tecnologia, Portugal.

\section{REFERENCES}

Alcazar, R. 1998. Impactos da agricultura nas lagoas temporárias do Parque Natural do Sudoeste Alentejano e Costa Vicentina. Estágio de licenciatura. Faculdade de Ciências da Universidade de Lisboa, Lisboa.

Alonso, M. 1978. Las lagunas de España Peninsular. Limnética, 15: 1-176.

Alonso, M. 1987. Ejemplos de vicarianza en comunidades de crustaceos de lagunas esteparias. Limnética, 3: 81-89.

Alonso, M. 1991. Review of Iberian Cladocera with remarks on ecology and biogeography. Hydrobiologia, 225: 37-43. DOI: $10.1007 / \mathrm{BF} 00028383$

Alonso, M. 1996. Crustacea. Branchiopoda. In: Ramos, M.A. (Ed.), Fauna Iberica, vol. 7. Museo Nacional de Ciencias Naturales, CSIC, Madrid.

Anonymous, 2002. The Ramsar Strategic Plan 2003-2008. Wetlands: water, life, and culture, $8^{\text {th }}$ Meeting of the Conference of the Contracting Parties to the Convention on Wetlands (Ramsar, Iran, 1971), Valencia, Spain, 18-26 November 2002. Available at http://ramsar.org/key_strat plan_2003_e.htm (accessed 1 July 2009)

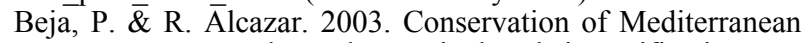 temporary ponds under agricultural intensification: an evaluation using amphibians. Biol. Conserv., 114: 317326. DOI: 10.1016/S0006-3207(03)00051-X.

Boix, D., J. Sala \& R. Moreno-Amich. 2001. The faunal composition of Espolla pond (NE Iberian Peninsula): the neglected biodiversity of temporary waters. Wetlands, 21: 577-592. DOI: 10.1672/0277-5212(2001)021[0577: TFCOEP]2.0.CO;2

Boix, D., J. Sala, X.D. Quintana \& R. Moreno-Amich. 2004. Succession of the animal community in a Mediterranean temporary pond. J. N. Am. Benthol. Soc., 23: 29-49. DOI: 10.1899/0887-3593(2004)023<0029:SOTACI >2.0.CO;2

ter Braak, CJF. 1995. Ordination. In: Jongman, R.H.G., C.J.F. ter Braak, \& O.F.R. van Tongeren (Eds), Data analysis in community and landscape ecology. Cambridge University Press, Cambridge: 91-173.

ter Braak, C.J.F. \& P. Smilauer. 1998. Canoco Reference Manual and User's Guide to Canoco for Windows: Software for Canonical Community Ordination Version 4.0. Microcomputer Power, Ithaca, New York.

Brucet, S., D. Boix, R. López-Flores \& A. Badosa. 2005. Zooplankton structure and dynamics in permanent and temporary Mediterranean salt marshes: taxon-based and sizedbased approaches. Arch. Hydrobiol., 162: 535-555. DOI: 10.1127/0003-9136/2005/0162-0535.

Bruno, M.C., W.F. Loftus, J.W. Reid \& S.A. Perry. 2001. Diapause in copepods (Crustacea) from ephemeral habitats with different hydroperiods in Everglades National Park (Florida, U.S.A.). Hydrobiologia, 453/454: 295-308. DOI: 10.1023/A:1013161210836. 
Chaves, M.L.C. 1999. Monitorização biológica de lagoas temporárias mediterrânicas. Contribuição para a definição de estados de referência. Relatório de licenciatura, Faculdade de Ciências da Universidade de Lisboa, Lisboa.

Cody, M.L. 1975. Towards a theory of continental species diversities: bird distributions over Mediterranean habitat gradients. In: Cody, M.L. \& J.M. Diamond (Eds), Ecology and Evolution of Communities. Belknap Press, Harvard: 214-257.

Collinson, N.H., J. Biggs, A. Corfield, M.J. Hodson, D. Walker, M. Whitfield \& P.J. Williams. 1995. Temporary and permanent ponds: an assessment of the effects of drying out on the conservation value of aquatic macroinvertebrate communities. Biol. Conserv., 74: 125-133.

Commission of the European Communities 2006. Halting the loss of biodiversity by 2010 - and beyond. Sustaining ecosystem services for human well-being. $\operatorname{COM}(2006) 216$ final: $15 \mathrm{pp}$.

Dussart, B.H. 1967a. Contribution à l'étude des Copépodes d'Espagne. Publicaciones del Instituto de Biología Aplicada de Barcelona, 42: 87-105.

Dussart, B.H. 1967b. Les copepodes des eaux continentales d'Europe occidentale. Tome I: Calanoïdes et Harpacticoïdes. Editions N. Boubée \& Cie, Paris.

Dussart, B.H. 1969. Les Copépodes des eaux continentales d'Europe occidentale. II. Cyclopoïdes et Biologïe. Editions N. Boubée \& Cie. Paris.

EPCN - European Conservation Pond Network, Third workshop, Valencia Spain, 14-16 May 2008. Available at http://campus.hesge.ch/epcn/posters_valencia08.asp (accessed 1 June 2009).

Fahd, K., L. Serrano \& J. Toja. 2000. Crustacean and rotifer composition of temporary ponds in the Doñana National Park (SW Spain) during floods. Hydrobiologia, 436: 4149. DOI: $10.1023 / \mathrm{A}: 1026577619151$.

Fahd, K., M. Florencio, C. Keller \& L. Serrano. 2007. The effect of the sampling scale on zooplankton community assessment and its implications for the conservation of temporary ponds in south-west Spain. Aquat. Conserv., 17: 175-193. DOI: $10.1002 /$ aqc.781.

Fidalgo, M.L. \& M.T. Monteiro. 2004. A note on the presence of Dussartius baeticus (Dussart, 1967) in Portugal (Copepoda, Calanoida). Crustaceana, 76: 1399-1407.

Fisher, R.A., A.S. Corbet \& C.B. Williams. 1943. The relationships between the number of species and the number of individuals in random samples of an animal population. J. Anim. Ecol., 12: 42-58.

Frisch, D., E. Moreno-Ostos \& A.J. Green. 2006. Species richness and distribution of copepods and cladocerans and their relation to hydroperiod and other environmental variables in Doñana, south-west Spain. Hydrobiologia, 556: 327-340. DOI 10.1007/s10750-005-1305-z.

Galindo, M.D., N. Mazuelos, J.A. Mata \& L. Serrano. 1994. Microcrustacean and rotifer diversity and richness relating to water temporality in different ponds in the Doñana National Park. Int. Ver. Theor. Angew., 25: 1350-1356.

Green, J. 1985. Horizontal variations in associations of zooplankton in Lake Kariba. J. Zool., 206: 225-239.

Grillas, P., P. Gauthier, N. Yavercovski \& C. Perennou (Eds). 2004a. Mediterranean Temporary Pools. Vol 1. Issues relating to conservation, functioning and management. Station Biologique de la Tour du Valat: $120 \mathrm{p}$.

Grillas, P., P. Gauthier, N. Yavercovski \& C. Perennou (Eds). 2004b. Mediterranean Temporary Pools. Vol 2. Species information sheets. Station Biologique de la Tour du Valat: $130 \mathrm{p}$.

Girdner, S.F. \& G.L. Larson. 1995. Effects of hydrology on zooplankton communities in high-mountain ponds, Mount Rainier National Park, USA. J. Plankton Res., 17: 1731-1755.
Hill, M.O. 1973. Diversity and evenness: a unifying notation and its consequences. Ecology, 54: 427-431. DOI: $10.2307 / 1934352$.

Holm-Hansen, O. \& B. Rieman. 1978. Chlorophyll- $a$ determination: improvements in methodology. Oikos, 30: 438-447.

Kiefer, F. 1978. Das zooplankton der Binnengewasser. Freilebende Copepoda. Die Binnengewasser, 26: 1-343.

Korn, M., F. Marrone, J.L. Perez-Bote, M. Machado, M. Cristo, L.C. Fonseca \& A.K. Hundsdoerfer. 2006. Sister species within the Triops cancriformis lineage (Crustacea, Notostraca). Zool. Scr., 35: 301-322. DOI: 10.1111/j.1463-6409.2006.00230.x.

Legendre, P. \& L. Legendre. 1998. Numerical Ecology, $2^{\text {nd }}$ ed. Elsevier, Amsterdam.

Machado, M., M. Cristo \& L.C. Fonseca. 1999a. Non-cladoceran Branchiopod crustaceans from southwest Portugal. I. Occurrence notes. Crustaceana, 72: 591-602. DOI: $10.1163 / 156854099503636$.

Machado, M., M. Cristo, J. Reis \& L.C. Fonseca. 1999b. Biological data on Triops cancriformis mauritanicus (Ghigi, 1921) and Cyzicus grubei (Simon, 1886) - Crustacea, Branchiopoda - in SW Portugal temporary ponds. Limnética, 16: 1-7.

Mahoney, D.L., M.A. Mort \& B.E. Taylor. 1990. Species richness of calanoid copepods, cladocerans and other branchiopods in Carolina bay temporary ponds. Am. Midl. Nat., 123: 244-258.

Marrone, F., R. Barone \& L.N. Flores. 2006. Ecological characterization and cladocerans, calanoid copepods and large branchiopods of temporary ponds in a Mediterranean island (Sicily, southern Italy). Chem. Ecol., 22 (4): 181-190. DOI: $10.1080 / 02757540600557827$.

Miracle, M.R. 1982. Biogeography of the freshwater zooplanktonic communities of Spain. J. Biogeogr., 9: 455-467.

Murphy, J. \& J.P. Riley. 1962. A modified single solution method for the determination of phosphate in natural waters. Anal. Chim. Acta, 27, 31-36.

Proctor, H.C. \& G. Pritchard. 1989. Neglected predators: water mites (Acari: Parasitengona: Hydrachnelle) in freshwater communities. J. N. Am. Benthol. Soc., 8: 100-111.

Reid, J.W. 1996. Dussartius baeticus. In: IUCN 2008. 2008 IUCN Red List of Threatened Species. Version 2009.1. Available at http://www.iucnredlist.org/details/6930 (accessed 1 June 2009).

Rzóska, J. 1961. Observations on tropical rainpools and general remarks on temporary waters. Hydrobiologia, 27: 265-286. DOI: 10.1007/BF00036336.

Scourfield, D.J. \& J.P. Harding. 1966. A key to the British Freshwater Cladocera with notes on their ecology. Freshwater Biological Association, Windermere: $55 \mathrm{pp}$.

Serrano, L. \& K. Fahd. 2005. Zooplankton communities across a hydroperiod gradient of temporary ponds in the Doñana National Park (SW Spain). Wetlands, 25(1): 101111. DOI: 10.1672/0277-5212(2005)025[0101:ZCAAHG] 2.0.CO;2.

Serrano, L. \& J. Toja. 1995. Limnological description of four temporary ponds in the Doñana National Park (SW, Spain). Arch. Hydrobiol., 133: 497-516.

Serrano, L. \& J. Toja. 1998. Interannual variability in the zooplankton community of a shallow temporary pond. Int. Ver. Theor. Angew., 26: 1575-1581.

Shapiro, J. 1990. Biomanipulation: The next phase - making it stable. Hydrobiologia, 200/201: 13-27. DOI: 10.1007/BF 02530325 .

Simpson, E.H. 1949. Measurement of diversity. Nature, 163: 688. DOI: $10.1038 / 163688 \mathrm{a} 0$.

Tachet, H., P. Richoux, M. Bournaud \& P. Usseglio-Polatera. 2000. Invertébrés d'eau douce. Systématique, biologie, écologie, Paris: CNRS Editions: 588 pp. 
Thorp, J.H. \& A.P. Covich (Eds). 2001. Ecology and Classification of North American Invertebrates. $2^{\text {nd }}$ Edition, Academic Press, 297-775.

Van den Brink, F.W.B., M.M. Van Katwijk \& G. Van der Velde. 1994. Impact of hydrology on phyto- and zooplankton community composition in floodplain lakes along the Lower Rhine and Meuse. J. Plankton Res., 16: 351-373.

Whittaker, R.H. 1960. Vegetation of the Siskiyou Mountains, Oregon and California. Ecol. Monogr., 30: 279-338. DOI: $10.2307 / 1943563$.

Whittaker, R.H. 1967. Gradient analysis of vegetation. Biol. Rev., 42: 207-264.

Whittaker, R.H. 1972. Evolution and measurement of species diversity. Taxon, 21: 213-251. DOI:10.2307/1218190.

Received: July 2009

Accepted: October 2009
Wiggins, G.B., R.J. Mackay \& I.M. Smith. 1980. Evolutionary and ecological strategies of animals in annual temporary ponds. Arch. Hydrobiol. Suppl., 58: 97-206.

Williams, W.D. 2000. Biodiversity in temporary wetlands of dryland regions. Int. Ver. Theor. Angew., 27: 141-144.

Wilson, M.V. \& A. Shmida. 1984. Measuring beta diversity with presence-absence data. J. Ecol., 72: 1055-1064.

Wyngaard, G.A., B.E. Taylor \& D.L. Mahoney. 1991. Emergence and dynamics of cyclopoid copepods in an unpredictable environment. Freshwat. Biol., 25: 219-232.

Yentsch, C.S. \& D.W. Menzel. 1963. A method for the determination of phytoplankton chlorophyll and phaeophytin by fluorescence. Deep Sea Res., 10: 221-231. 